УДК 343.131(477)

DOI https://doi.org/10.32837/yuv.v0i2.1719

М. Сіроткіна,

кандидат юридичних наук,

докторантка кафедри правосуддя

Київського національного університету імені Тараса Шевченка

\title{
УГОДА ПРО ВИЗНАННЯ ВИНУВАТОСТІ У КРИМІНАЛЬНОМУ ПРОВАДЖЕННІ ЯК ОДНА 3 КОМПРОМІСНИХ ФОРМ ВИРІШЕННЯ ПРАВОВОГО КОНФЛІКТУ
}

На шляху реформування кримінального судочинства та наближення його до міжнародних стандартів наша держава взяла на себе певні зобов'язання перед міжнародною спільнотою. Серед основних - це викорінення корупційних явищ, суттєва оптимізація роботи судових органів, прокуратури, адвокатури, досудового розслідування, створення та налагодження діяльності відповідних органів та інституцій, які б сприяли належному захисту прав та законних інтересів особи в нашому суспільстві.

Парламентська асамблея Ради Європи зазначає, що в багатьох державах-членах Ради Європи та в державах, які мають статус спостерігача або інший статус у Раді Європи або Асамблеї, постійні кримінальні процеси поступово були замінені різними формами систем відмови від судового розгляду (які також називаються узгодженим визнанням вини, визнанням себе винним, скороченими судовими розглядами або спрощеним судочинством). У низці країн лише меншість засуджень у кримінальному порядку все ще засновується на регулярних судових процесах [1].

Подібні форми здійснення кримінального судочинства із прийняттям чинного КПК України у 2012 році все ширше застосовуються і в Україні. Однією з них є можливість досягнення угоди про примирення або про визнання винуватості, можливе застосування деяких елементів процедури медіаціі, пробація, амністія; звільнення від кримінальної відповідальності та кримінального покарання; вирішення цивільного позову у кримінальному судочинстві та інше, що значно впливає на якість та швидкість досудового розслідування та здійснення правосуддя.

Дослідженню інституту угод у кримінальному судочинстві (та споріднених із ними правових процедур) присвятили свої праці Л.В. Головко, Ю.М. Грошевий, К.Ф. Гуценко, В.В. Дорошков, В.О. Лазарєва, О.М. Лемешко, Л.М. Лобойко, В.Г. Лукашевич, Р.Б. Майманова, В.Т. Маляренко, Р.В. Новак, В.Т. Нор, M.А. Пешков, Є.В. Повзик, П.В. Пушкар, Г.Ю. Саєнко, О.В. Стратій, О.М. Тісен, M.I. Хавронюк та інші. Водночас можна констатувати, що із прийняттям 13 квітня 2012 року чинного КПК України розширились можливості досягнення компромісу у кримінальному провадженні, але можливості укладання компромісних угод ще недостатньо грунтовно розроблені в науковій літературі, що викликає низку запитань у практичній діяльності працівників слідчих підрозділів, прокуратури й суду.

Згідно зі ст. 468 КПК України у кримінальному провадженні можуть бути укладені такі види угод:

1) угода про примирення між потерпілим та підозрюваним чи обвинуваченим;

2) угода між прокурором та підозрюваним чи обвинуваченим про визнання винуватості [2]. 
Запровадження цього різновиду особливого порядку кримінального провадження у вітчизняне законодавство переслідує загальну мету - якісно вплинути на стан кримінального судочинства в Україні. Закріплення у кримінальному процесуальному законі інституту угод полягає у створенні нової ідеології кримінальної політики нашої держави: протидія злочинності через компроміс, договір, без інституту угод концепція компромісу позбавлена своєї основи [3, с. 112].

Привертають до себе увагу відмінності в поглядах науковців щодо визначення самого поняття угоди про визнання винуватості, ї сутності та правової природи, як на:

1) прискорення кримінального процесу;

2 ) інститут кримінального процесу, спрямований на процесуальну економію, спрощення та скорочення процедури розгляду кримінальних проваджень;

3) диференціацію кримінальної процесуальної форми;

4) співробітництво із правоохоронними органами;

5) засіб розв'язання кримінальних конфліктів завдяки компромісу;

6) домовленість сторін, що буде проаналізовано далі.

Варто звернути увагу на те, що щодо поняття та сутності угоди про визнання винуватості думки науковців між собою різняться, а це потребує додаткового аналізу. На нашу думку, така ситуація зумовлена тим, що різні науковці досліджували це поняття в певних аспектах, під різними кутами зору, без здійснення системного підходу, що потребує певного узагальнення, оскільки інститут укладення угоди містить у собі як елементи процесуальної економії, спрощення кримінального провадження, так і диференціації кримінальної процесуальної форми, досягнення компромісу та, загалом, $€$ способом вирішення кримінально-правового конфлікту.
Щодо інституту досягнення угоди як способу прискорення кримінального провадження виникає низка сумнівів. Ще у 70-х роках минулого століття О.С. Кобліков наголошував, що прискорення кримінального провадження $€$ важливим, проте не основним завданням, яке досягається за допомогою застосування інституту угод у кримінальному провадженні. Важливо звернути увагу й на те, що, визнаючи швидкість судочинства однією з умов успіху в боротьбі зі злочинністю, дослідники застерігають від поспішності, вказуючи, що на виправлення помилок завжди потрібно набагато більше часу й засобів, ніж на підготовку та прийняття правильного первісного рішення [4, с. 63-64].

3 огляду на викладене, як правильно зазначають М.П. Поляков, О.Ю. Смолін, Г.Є. Тюрін, процесуальне призначення цього інституту необхідно розуміти більш широко - як забезпечення максимально раціонального здійснення кримінального провадження, яке окремими дослідниками пов'язується 3 поняттям «процесуальна економія». Остання полягає не лише у швидкості, простоті й дешевизні судочинства, а й у швидкому та повному досягненні його мети, не пов'язаному з надмірними (необгрунтованими) матеріальними витратами й підкріпленому системою необхідних процесуальних гарантій [5, с. 61,6 , с. 10].

Науковці I.M. Канюка, В.А. Савченко та інші у своїх дослідженнях доходять висновку, що досягнення угоди у кримінальному провадженні $€$ виявом спрощення кримінального провадження. Завдяки цьому інструменту завдання кримінального судочинства досягаються швидше, економніше й безболісніше для зацікавлених осіб» [7, с. 78]. Щодо цього можна додати, що будь-яка спрощена форма кримінального провадження сприяє швидкості вирішення правового конфлікту, економії часу й ресурсів під час досудового розслідування та судового розгляду кримінальних проступків чи злочинів, 
зокрема вказаних у ч. 4 ст. 469 КПК України, зменшує морально-психологічне навантаження на потерпілу особу та підозрюваного чи обвинуваченого.

На нашу думку, є хибним заперечення факту спрощення кримінального провадження під час укладення угоди. Однак ми вважаємо, що зводити укладення угоди, як й інші спрощені форми кримінальної процесуальної форми (провадження щодо кримінальних проступків, провадження у формі приватного обвинувачення), лише до економії часу та ресурсів у кримінальному провадженні буде неправильним. Процесуальна економія в цьому разі не $є$ самоціллю, головним залишається виконання завдань кримінального провадження, вказаних у ст. 2 КПК України, серед яких не лише вимога «швидкого», а й «повного та неупередженого розслідування та судового розгляду», а також щоб «до кожного учасника кримінального провадження була застосована належна правова процедура» [2]. А пріоритетним $є$ виконання завдання захисту прав і свобод людини i громадянина, які потрапили у сферу кримінального судочинства, охорона ї прав, свобод та законних інтересів. Відповідно, процесуальна економія чи спрощення кримінальної процесуальної процедури не можуть суперечити захисту основних цінностей держави, а, навпаки, таке спрощення має слугувати насамперед не інтересам здешевлення судочинства за кошт обвинуваченого та потерпілого, а інтересам названих осіб із метою недопущення надмірної тяганини та морально-психологічного тиску на них, чого вимагає й засада розумності строків кримінального провадження (ст. 28 КПК України).

У цьому контексті B.M. Тертишник справедливо стверджує, що умови угоди повинні відповідати певним принципам, мати гарантії істини та справедливості, а також зауважує, що якщо таких гарантій замало - є небезпека судових помилок і зловживань, якщо їх забагато - можлива судова тяганина, за якої можуть бути забутими та химер- ними, власне, цілі судочинства. Оптимальним варіантом є розумна достатність гарантій [8, с. 88].

Варто також підтримати думку тих науковців, які говорять про досягнення угоди як про вияв диференціації кримінально-процесуальної форми.

Учений П.В. Холодило схиляється до думки, що для визначення сутності якісно нової форми (якою є угода про визнання винуватості) потрібен підхід, який дозволить виокремити наявність «якісних» конструктивних відмінностей нової форми, але оскільки ця форма $€$ органічним цілим із кримінальним процесом України, то виокремлення (як диференційованої форми) необхідно здійснювати за критеріями, котрі наявні в основній формі кримінального процесу. До цих критеріїв учений відніс такі: суспільна небезпека злочину; дія в певній стадії кримінального провадження; ініціатор угоди; добровільність укладення угоди; визнання вини; співробітництво зі слідством; наслідки укладення та затвердження угоди; особливості судового розгляду; наявність суспільного інтересу в запобіганні, виявленні чи припиненні більшості кримінальних правопорушень або інших більш тяжких кримінальних правопорушень; форма укладення та деякі інші [9, с. 60-61].

Не можна, на наш погляд, розглядати угоду про визнання винуватості суто 3 позиції «угоди про співробітництво», яка знайшла своє закріплення у кримінально-процесуальному законодавстві США, Росії та низці інших країн. Відповідно до параграфів 129, 129a КК ФРН суд узагалі може не лише призначити більш м'яке покарання, a і звільнити особу від покарання взагалі, якщо та добровільно та своєчасно повідомила правоохоронним органам про діяльність організованого злочинного угрупування чи терористичної організації, про їх учасників та злочинні цілі, чим перешкодила їх подальшому функціонуванню [10, с. 74, 75].

В Україні такі угоди у КПК окремо не закріплено. Тим не менше бажання співробітничати зі стороною обвину- 
вачення, щире каяття, визнання своєї винуватості $€$ елементами й угоди про визнання винуватості і в Україні. Однак у такій формі йдеться суто про співробітництво з органами кримінального переслідування, яке сприяє розкриттю та розслідуванню злочинів, викриттю винних та перешкоджає злочинній діяльності інших осіб, злочинних груп чи організацій, а не лише про визнання підозрюваним чи обвинуваченим своєї винуватості, що є другорядним.

Проаналізувавши все вищезазначене, доходимо висновку, що інститут угоди у кримінальному судочинстві можна розглядати 3 різних позицій: і як прискорення кримінального провадження, і його спрощення, і як прояв диференціації кримінально-процесуальної форми тощо. Однак, на нашу думку, в основі угоди, як про примирення, так і про визнання винуватості, лежить компроміс. Саме це і становить його внутрішню сутність. Зрештою угода й означає «компроміс»: (у перекладі з латині “compromissum" - угода, згода) - «згода з ким-небудь у чомусь, що досягається взаємними вчинками; поступка заради досягнення мети» [11, с. 196-197].

Як і будь-яка угода, інститут угоди у кримінальному процесі передбачає згоду сторін з істотних питань кримінального права та процесу в конкретній справі, їх взаємні права й обов'язки, а також певні переваги, які отримує кожна зі сторін унаслідок укладення й реалізації угоди. Це, зі свого боку, дозволяє розглядати інститут угод у кримінальному провадженні в контексті реалізації ідей кримінально-правового компромісу.

Згідно зі ст. 468 чинного КПК Україн досягнення такого компромісу можливе між прокурором та підозрюваним чи обвинуваченим шляхом укладення між ними угоди про визнання винуватості та між потерпілим та підозрюваним чи обвинуваченим шляхом укладення угоди про примирення [2].

В основі досягнення угоди у кримінальному провадженні, як і будь-якої угоди загалом, лежить інтерес зацікавлених сторін. Інтересбудь-якого суб'єкта домовленостей чи угоди виступає рушійним фактором для досягнення згоди між ними, що, на нашу думку, спонукало законодавця створити правове поле для законодавчого закріплення такої можливості та розширення приватного «інтересу» у кримінальному процесі через процедуру кримінального провадження на підставі угод.

Забезпечуючи пріоритет державних (публічних) інтересів, законодавець передбачив у кримінальному провадженні на підставі угоди лише мінімальний обсяг процесуальних засобів для доведення винуватості особи (за умови згоди обвинуваченого), встановивши, що цього буде достатньо для досягнення поставленої мети перед правосуддям. Одночасно надано переважне право стороні обвинувачення та захисту на власний розсуд обирати можливість домовлятись про врегулювання конфлікту чи ні. Такий підхід забезпечив баланс рівноваги між публічними та приватними інтересами у кримінальному провадженні. Крім того, такий законодавчий підхід став підставою виникнення дуальності у кримінальному процесі. Зокрема, сторони у кримінальному провадженні на підставі угод виступають не лише сторонами у справі, у провадженні, a одночасно i сторонами угоди, яка $€$ невід'ємним складником згаданого провадження [12, с. 48].

Доречно буде сказати, що, наприклад, у кримінальному процесі ФРН досягнення подібного компромісу є його основним завданням. Як зазначається дослідниками, в німецькому кримінально-процесуальному законодавстві наявна диференціація завдань кримінального судочинства, які поділяються на основні та другорядні. Основним загальновизнаним серед них $€$ не забезпечення покарання злочинця, а досягнення «правового миру» - оптимального правового компромісу між державою - злочинцем, державою - потерпілим, потерпілим злочинцем [13, с. 30-35]. 
Досягнення угоди у кримінальному провадженні різними науковцями тлумачиться по-різному: як прискорення кримінального процесу; інститут кримінального процесу, спрямований на процесуальну економію; диференціацію кримінальної процесуальної форми; форму співробітництва із правоохоронними органами; засіб розв'язання кримінальних конфліктів завдяки компромісу; домовленість сторін. На перший погляд здається, що угодам у кримінальному провадженні тією чи іншою мірою притаманні всі перелічені ознаки, однак в основі угоди лежить компроміс, етимологічне значення терміну якого в перекладі з латини означає «угода», яка досягається взаємними поступками на взаємовигідних умовах із метою залагодження правового конфлікту.

У статті на основі чинного кримінального процесуального законодавства та новітніх наукових напрацювань висвітлено дослідження щодо процесуального механізму укладення угоди про визнання винуватості у кримінальному провадженні. Констатуеться, що в різних країнах постійні кримінальні процеси поступово замінюються формами систем відмови від судового розгляду, які також називаються узгодженим визнанням вини, визнанням себе винним, скороченими судовими розглядами або спрощеним судочинством. Із прийняттям 13 квітня 2012 року чинного КПК України розширились можливості досягнення компромісу у кримінальному провадженні, але можливості укладання компромісних угод ще недостатньо трунтовно розроблені в науковій літературі, що викликае низку запитань у практичній діяльності працівників слідчих підрозділів, прокуратури й суду.

Установлено, що досягнення угоди у кримінальному процесі науковиями розуміється як прискорення кримінального процесу; інститут кримінального процесу, спрямова- ний на процесуальну економію, спрощення та скорочення процедури розгляду кримінальних проваджень; диференціація кримінальної процесуальної форми; співробітництво із правоохоронними органами; засіб розв'язання кримінальних конфліктів завдяки компромісу; домовленість сторін. Це зумовлено головним чином тим, що різні науковці досліджвали ие поняття в певних аспектах, під різними кутами зору, без здійснення системного підходу, що потребує певного узагальнення, оскільки інститут укладення угоди містить у собі як елементи проце суальної економії, спрощення кримінального провадження, так $і$ диференціації кримінальної процесуальної форми, досягнення компромісу та, загалом, е способом вирішення кримінально-правового конфлікту.

Доводиться, що угодам у кримінальному провадженні тією чи іншою мірою притаманні всі перелічені ознаки, однак в основі угоди лежить компроміс, що в перекладі з латини означає «угода», яка досягається взаємними поступками на взаємовигідних умовах із метою залагодження правового конфлікту.

Ключові слова: компроміс, кримінально-процесуальна форма; процесуальна економія, співробітництво, угода про визнання винуватості.

Sirotkina $M$. Plea agreement in criminal proceedings as one of the compromise forms to resolve a legal conflict

Based on current criminal procedural legislation and the latest scientific elaborations this article is highlighting a research regarding procedural mechanism of concluding plea agreement in criminal proceedings. It is noted that in various countries ongoing criminal proceedings are gradually being replaced by forms and systems of refusal from judicial examination which are also called as plea bargaining, confession of guilt, plea of guilty, 
summary trials or summary judgment. With adoption of the current CPC of Ukraine on 13 April 2012 there were expanded the possibilities to reach compromise in criminal proceedings. But these possibilities to conclude compromise agreements have not been yet thoroughly elaborated in the scientific literature. It raises a range of questions in the practical activity of representatives of investigative units, public prosecution offices and courts.

It is established that scientists understand reaching an agreement in the criminal process as the acceleration of the criminal process; institution of criminal process aimed at procedural economy, simplification and reduction of the criminal proceedings; differentiation of criminal procedural form; cooperation with law enforcement agencies; a way to resolve criminal conflicts by means of compromise; agreement between the parties. This is mainly due to a fact that various scholars have researched this notion in certain aspects, in various perspectives, without a systematic approach that requires for some generalization, since the institution of the agreement contains both elements of procedural economy, simplification of criminal proceedings, and differentiation criminal procedural form, reaching compromise and, in general, is a way to resolve a criminal conflict.

It is argued that the agreements in criminal proceedings, to some extent, have all these features. However, at the heart of agreement is compromise that means in Latin "agreement" which is reached by mutual concessions on mutually beneficial terms with the aim to settle a legal conflict.

Key words: compromise, criminal procedural form; procedural economy, cooperation, plea agreement.

\section{Література}

1. Резолюиія ПАРЕ № 2245 (2018) «Укладання угод у кримінальному провадженні: необхідність мінімальних стан- дартів для систем відмови від судового розгляду». URL : https://www.echr.com. ua / document / rezolyuciya-parye-2245-2018.

2. Кримінальний проиесуальний кодекс України № 4651-VI від 13 квітня 2012 року. Верховна Рада України. URL: http:// zakon2.rada.gov.ua/laws/show/4651-17.

3. Бандурка О. М., Блажівський Є. М., Бурдоль Є. П. Кримінальний проиесуальний кодекс України. Науково-практичний коментар : у 2 m.; за заг. ред. В.Я. Тація, В.П. Пшонки, А.В. Портнова. Харків : Право, 2013. Т. 1. 768 с.

4. Кобликов А.С. Законность - конституционный принцип советского уголовного судопроизводства. Москва : Юрид. лит., 1979. $200 \mathrm{c}$.

5. Поляков М.П., Смолин А.Ю. Принциип процессуальной экономии в уголовном судопроизводстве : монография. Н. Новгород : Нижегород. акад. МВД России, 2011. 152 c.

6. Тюрін Г.Є. Організаційно-правові основи участі прокурора у кримінальному провадженні на підставі угод : монографія. Харків : Право, 2015. 288 с.

7. Канюка I.M., Савченко В.А., Савчук P.M., Харевич P.М. Принции процесуальної економії у кримінальному судочинстві України : монографія. Івано-Франківськ : Голіней O.М., 2020. 115 c.

8. Тертышник В.М. Без суда и следствия: острые угль судебно-правовой реформы. Держава. 2000. № 41. С. 87-95.

9. Холодило П.В. Кримінальне провадження на підставі угод про визнання винуватості : дис. ... канд. юрид. наук : 12.00.09. Київ : Нац. акад. внутр. справ, 2017. 296 c.

10. Strafgesetzbuch. 40 Aufl. Verlag C.H. Beck. Monchen. Texte im dtv, 2005. $309 \mathrm{~s}$.

11. Юридична енииклопедія : в 6 m. T. 3 : Київ-Москва / НАН України. Iн-m держави $і$ права імені В.М. Корецького ; голова редкол. Ю.С. Шемшученко ; редкол. : М.П. Зяблюк, В.Д. Горбатенко. Київ : Вид-во «Українська енциклопедія» імені М.П. Бажана, 2001. 792 с.

12. Саєнко Г.Ю. Провадження на підставі угод у кримінальному процесі України : дис. ... канд. юрид. наук : 12.00.09. Київ : Нац. акад. внутр. справ. 2017. 243 с.

13. Савченко В.А., Соловій Я.І., Фелик В.І., Юрчищин В.Д. Основи кримінального прочесу Федеративної Республіки Німеччина : навч. посібник. Харків : Право, 2017. 372 c. 